(C) 2020 Katedra Białorutenistyki UW. Wydanie w otwartym dostępie na licencji CC BY-NC-ND (https://creativecommons.org/licenses/by-nc-nd/4.0/deed.pl)

ACTA ALBARUTHENICA 20: 2020

DOI: 10.32612/uw.18988091.2020.20.pp.239-253

Марына Свістунова / Maryna Svistunova

Беларускі дзяржаўны ўніверсітэт / Belarusian State University

ORCID: https://orcid.org/0000-0001-8856-9530

e-mail:svistunovami@bsu.by

\title{
Да праблемы пераемнасці беларускай літаратурнай мовы: лацінаграфічныя тэксты XVIII стагоддзя
}

On the problem of continuity of the Belarusian literary language:

Latin graphic texts of the XVIII century

Do problemu ciagłości białoruskiego języka literackiego:

teksty XVIII wieku napisane alfabetem łacińskim

\section{1. Праблема пераемнасці беларускай мовы ў навуковай літаратуры}

Да праблемы пераемнасці паміж старабеларускай і новай беларускай літаратурнай мовай айчынныя навукоўцы звярталіся не аднойчы і вырашалі яе па-рознаму. I калі на пачатку XX ст. Яўхім Карскі, Осіп Воўк-Левановіч, а пазней - Кандрат Крапіва, Аркадзь Жураўскі, Іван Крамко, Леў Шакун і інш. сцвярджалі наяўнасць перарыву пісьмовай традыцыі і, адпаведна, адсутнасць пераемнасці, то Уладзімір Анічэнка і Арцём Баханькоў адзначалі бесперапыннасць і эвалюцыйны характар гэтага працэсу. Агульнапрыняты погляд на праблему, падмацаваны аўтарытэтам вядучых у гэтай галіне навукоўцаў, доўгі час не падлягаў перагляду і нават крытычнаму аналізу. Аднак развіццё ўласна гістарычнай навукі, стварэнне і прыманне канцэпцыі шматмоўнай літаратуры Беларусі, больш грунтоўнае вывучэнне існуючых, а таксама выяўленне невядомых у савецкім гістарычным мовазнаўстве помнікаў пісьменства вельмі павольна, але вядуць да неабходнасці перагляду або, як мінімум, верыфікацы традыцыйнага вырашэння гэтай праблемы. У апошнія дзесяцігоддзі Ірына Будзько, Ірына Гапоненка, Ганна Кулеш, Валянціна Мароз, Святлана Струкава, Галіна Ціванова і інш. непасрэдна ці ўскосным чынам у сваіх публікацыях разглядалі існуючыя і выказвалі ўласныя меркаванні адносна таго, быў ці не перарыў у пісьмовай традыцы беларускай мовы, прымаючы пад увагу пры гэтым розныя аспекты яе рэалізацыі ў дыяпазоне ад літаратурных стыляў і жанраў да народна-гутарковага і дыялектнага маўлення. 
Асобна трэба адзначыць актыўную навуковую дзейнасць у апошняе дзесяцігоддзе ў межах акрэсленай праблематыкі польскай даследчыцы Яанны Геткі, аўтара артыкулаў U progu modernizacji. Ruskojęzyczne drukarstwo bazyliańskie XVIII wieku (2017), Ruskojęzyczne wydania drukarni supraskiej o charakterze religijnym (XVIII wiek) - pominięty element $w$ badaniach nad historiq kultury białoruskiej (2018), Белорусский язык XVIII в. исследовательские постулаты (2018) і інш. [Getka 2017; Getka 2018; Гетка 2018]. Нават апярэджваючы многім беларускае гістарычнае мовазнаўства, Я.Гетка спрабуе аргументаваць адсутнасць перарыву ў пісьмовай традыцыі беларускай мовы, абапіраючыся на найбольш кансерватыўны ў справе адлюстравання рыс жывой народнай гаворкі стыль - рэлігійны. Яшчэ раней гісторык Юры Гардзееў адзначыў і апісаў беларускі ўплыў на польскую мову афіцыйна-справавога пісьменства XVIII ст. на прыкладзе канцылярскіх кніг Гародні [Гардзееў 2003; Gordziejew 2004a: 129-130; Gordziejew 2004b; Гардзееў 2007]. Абапіраючыся на аналіз мовы ананімнага сатырычнага твора 1642 г. (!), Марыля Хаўстовіч прапаноўвае “сцвердзіць пераемнасць паміж старой і новай беларускай літаратурнай мовамі, мовай статуту Вялікага Княства Літоўскага, мовай інтэрмедый і мовай Францішка Багушэвіча" [Хаўстовіч 2018: 279].

Вынікі і высновы даследаванняў, праведзеных названымі і іншымі польскімі калегамі, выступаюць каталізатарам і для беларускіх мовазнаўцаў.

Як справядліва заўважыла І. Гапоненка, “устанаўленне навуковых вывадаў па пытанні пераемнасці асабліва прынцыповым з'яўляецца для тых моў, якія зазналі неспрыяльнае ўмяшанне ў натуральныя эвалюцыйныя працэсы свайго развіцця" [Гапоненка 2010: 52]. I дададзім мае выключна важнае значэнне не толькі для фарміравання канцэпцыі гісторыі беларускай мовы, але і - больш шырока - для стварэння беларускай нацыянальнай прасторы.

Праблема пераемнасці непарыўна звязана з праблемай перыядызацыі гісторы беларускай літаратурнай мовы. Падзел на часавыя перыяды і вызначэнне іх храналагічных межаў у аспекце ўласна гісторыі, культуралогіi, гістарычнага літаратуразнаўства і мовазнаўства абапіраецца на розныя крытэрыі і факты, а таму не можа быць якасна і колькасна ідэнтычным. Аб'яднаныя наяўнасцю пісьмовай традыцыі і таму карэлятыўныя перыядызацыі гісторыі літаратурнай мовы і гісторы літаратуры, у “беларускім" выпадку маюць шэраг прынцыповых разыходжанняў. Напрыклад, праблемы перарыву у сучасным беларускім літаратуразнаўчым дыскурсе не існуе. Праілюструем гэтыя словы цытатамі з фундаментальнай працы Гісторыя беларускай літаратуры XI-XIX стагоддзяў:

Пераход ад даўняй да новай літаратуры, заняпад старой сістэмы літаратурных жанраў і працэс фарміравання новай жанравай сістэмы, выпрацоўка новых мастацкіх прынцыпаў і творчых метадаў адбываліся на 
беларускіх землях вельмі марудна і расцягнуліся на стагоддзі. Той уздым і росквіт, тыя станоўчыя тэндэнцыі, што назіраліся ў літаратуры эпохі Рэнесансу і ранняга барока, у надзвычай неспрыяльных гістарычных умовах другой паловы XVII-XVIII ст. не атрымалі далейшага развіцця. Амаль пагалоўная паланізацыя адукаваных колаў тагачаснага грамадства Беларусі, адсутнасць сваёй дзяржавы моцна стрымлівалі працэс станаўлення нацыянальна-гістарычнай самасвядомасці беларускага народа і не спрыялі развіццю беларускамоўнай літаратурнай творчасці, якая ледзь цеплілася ў пераходны перыяд. Спатрэбілася яшчэ амаль цэлае XIX ст. складанага беларуска-польска-рускага ўзаемадзеяння ва ўмовах самадзяржаўнай Расійскай імперыі, цяжкай, самаахвярнай, сапраўды гераічнай працы пачынальнікаў, каб у рэшце рэшт дайсці да Беларусі і падрыхтаваць глебу для новага, нацыянальнага Адраджэння і для з'яўлення вялікай беларускай літаратуры XX ст. [Гісторыя... 2006, I: 14].

Літаратура позняга барока. Беларуская літаратура другой паловы XVII - першай паловы XVIII ст. мела пераходны характар [Гісторыя... 2006, I: 824]. У развіцці беларускай літаратуры пераходнага перыяду выразна выдзяляюцца два этапы. У другой палове XVII - першай трэці XVIII ст. яна развіваецца пераважна ў рэчышчы барока. 3 30-60-х гадоў XVIII ст., у эпоху Асветніцтва, у беларускай літаратуры сталі праяўляцца класіцысцкія і (у меншай ступені) сентыментальныя тэндэнцыі [Гісторыя... 2006, I: 826].

Пачатак станаўлення новай літаратуры. Беларуская літаратура другой паловы XVIII ст. у адрозненне ад папярэдняга перыяду была ўжо прынцыпова іншай. <...> Завяршаецца пераходнасць ад старой літаратуры да новай, пра гэта сведчаць лепшыя творы другой паловы XVIII ст. <...> Старабеларуская і лацінская моўныя традыцыі ўтрымліваліся ў беларускай літаратуры да сярэдзіны XVIII ст. Рост адраджэнскіх тэндэнцый уласна беларускай літаратуры супаў з распаўсюджаннем польскай пісьмовай традыцыі. Адрыў беларускага пісьменства ад беларускай (часта сімбіёзу стараславянскай і беларускай) кніжнай мовы і зварот да народна-гутарковых пластоў здзяйсняўся перш за ўсё (як дапускала эстэтыка класіцызму) у “нізкіх" жанрах. Білінгвальная традыцыя, якая склалася ў пераходны перыяд, не дала выпасці беларускаму слову з пісьмовай традыцыі і перайшла з XVIII у XIX ст. [Гісторыя... 2006, II: 8].

Як вынікае з прыведзеных выказванняў, XVIII ст. характарызуецца як перыяд “надзвычай неспрыяльных гістарычных умоў”, падчас якога працэс развіцця беларускамоўнай літаратуры “ледзь цепліўся". Аднак, заўважым, што нават раздробленае і суаднесенае з рознымі перыядамі XVIII ст. тым не менш не выключаецца з перыядызацыі, як гэта часткова мае месца ў гісторы беларускай літаратурнай мовы, а сам працэс развіцця беларускай літаратуры ўяўляецца эвалюцыйным, няхай сабе і значна замаруджаным у акрэслены перыяд. Больш за тое, у апошняй цытаце сцвярджаецца пэўная лагічнасць адрыву ад кніжнай і зварот да народна-гутарковай мовы і адсутнасць перарыву пісьмовай традыцыі.

Аналагічны прынятаму ў гэтым выданні падзел на перыяды і вызначэнне іх храналагічных межаў знаходзім і ў іншых сучасных выданнях па гісторы беларускай літаратуры, дзе першая палова XVIII ст. 
адносіцца яшчэ да перыяду старабеларускай, а другая палова XVIII ст. да перыяду новай беларускай літаратуры.

Яшчэ адно прынцыповае адрозненне ўжо не паміж перыядызацыямі, але паміж самімі канцэпцыямі гісторы беларускай літаратуры і гісторыі беларускай літаратурнай мовы палягае ў тым, што аб'ектамі першай цалкам натуральна выступаюць старажытныя творы, напісаныя не толькі на беларускай, але і на лацінскай, і на польскай мовах. Гэта дазваляе, у сваю чаргу, гаварыць пра шматмоўную літаратуру Беларусі як пра своеасаблівы культурны і літаратурны феномен. Да аб'ектаў жа гісторыі беларускай літаратурнай мовы бясспрэчна адносяцца тэксты, запісаныя кірыліцай, на перыферыі згадваюцца лацінаграфічныя тэксты ${ }^{1}$ і зрэдку, у якасці экзатычнага элемента, - арабаграфічныя. Аднак, ролю і значэнне дадзеных тэкстаў нельга ацэньваць паводле колькасці, аб'ёму ці зместу напісанага і неабходна прызнаваць раўнапраўнымі аб’ектамі гісторыі беларускай літаратурнай мовы старажытнага перыяду, а само існаванне беларускай літаратурнай мовы ў розных графічных сістэмах - яе перманентнай характарыстыкай, нармальным станам, калі гаворка ідзе пра данацыянальныя перыяды.

Зыходзячы з актуальнасці і важнасці ўсяго вышэй адзначанага, у дадзеным артыкуле ўвага будзе засяроджана на даследаванні ролі лацінаграфічных тэкстаў XVIII ст. пры вырашэнні праблемы пераемнасці беларускай літаратурнай мовы.

\section{2. Адсутнасць беларускамоўных пісьмовых сведчанняў XVIII ст.}

Самым відавочным і моцным аргументам у абгрунтаванні наяўнасці перарыву ў пісьмовай традыцыі беларускай мовы з'яўляецца стэрэатыпнае меркаванне пра малалікасць як друкаваных, так і рукапісных помнікаў ад канца XVII і да пачатку XIX ст., пры гэтым XVIII ст. выглядае амаль цалкам запусцелым, праўда, апошнім друкаваным кірыліцай на старабеларускай мове творам прынята лічыць тэкст якраз першай чвэрці XVIII ст. - Собраніе прыпадковъ краткое... 1722 г. [Гісторыя... 1967, I: 356; Суша 2009: 108; Гетка 2018: 182] аўтарства супрасльскага архімандрыта (1709-1728) і грэка-каталіцкага мітрапаліта (1714-1728) Льва Кішкі. Большасць гісторыкаў мовы згодна, што першым творам на новай беларускай літаратурнай мове трэба лічыць Камедыю Каятана Марашэўскага 1787 г. [Жураўскі, Крамко 1973: 14; Анічэнка 1978: 52]. Такім чынам, 65 гадоў без пісьмовых сведчанняў на беларускай мове і сталі самым важным абгрунтаваннем існавання перарыву ў яе пісьмовай традыцыі і адсутнасці непасрэднай сувязі паміж

${ }^{1}$ Не можам пагадзіцца з выказаным Ганнай Жураўлёвай на старонках часопіса “Acta Albaruthenica" меркаваннем пра тое, што "асноўным алфавітам для беларускай мовы XVI-XVII стагоддзяў была лацінка" [Жураўлёва 2018: 254]. Патрабуе ўдакладнення і назіранне даследчыцы пра тое, што “ў XVIII стагоддзі ў некаторых творах на беларускай мове паралельна з лацінкай ужывалася кірыліца” [Жураўлёва 2018: 254]. 
двума суседнімі перыядамі - старабеларускай і перыядам новай беларускай літаратурнай мовы. Аднак такі падыход, нягледзячы на яго відавочную абгрунтаванасць, па сваёй сутнасці з'яўляецца вельмі фармальным і не ўлічвае асаблівасці функцыянавання беларускай мовы ў XVIII ст. і абумоўленае гэтым звужэнне сферы яе выкарыстання. Калі сучасная Няміга працякае пад горадам у жалезабетоннай трубе, то ці можам мы гаварыць, што яе няма?

Разам з тым існуюць і іншыя ацэнкі мовы названых "памежных" твораў. Так, Я. Гетка пра Собраніе прыпадковъ краткое... піша, што яго нельга разглядаць як адназначна беларускі твор і што ў такой самай пісьмовай традыцыі ў Супраслі былі надрукаваны і некаторыя больш познія творы 1759 і 1788 гг. [Гетка 2018: 182]. А аўтар дысертацыйнага даследавання Асаблівасці мовы беларускай пісьменнасці XVIII стагоддзя (1989) Г. Ціванова ў адным са сваіх пазнейшых артыкулаў выказваецца наступным чынам:

нельга лічыць мову гэтых твораў [інтэрмедый XVIII ст. - M. C.] прыналежнасцю беларускай нацыянальнай мовы: беларуская нацыя сфарміравалася ў XIX ст. Нацыянальная мова - мова стандартная; яе нормы кадыфікаваныя. Разам з тым мова твораў XVIII ст. адрозніваецца ад старабеларускай, паколькі апошняя эвалюцыянавала ад кніжна-славянскай традыцыі ў бок жывой мовы, так і не наблізіўшыся да яе ўшчыльную. Лёс прапанаваў нашай мове варыянт рэвалюцыйнага развіцця. У гэтым сэнсе адмаўляць наяўнасць перарыву ў развіцці мовы немагчыма [Ціванова 2010: 62].

Менавіта XVIII ст. “стаіць на стыку старой і новай эпох", а “творы новых літаратурных жанраў, якія нараджаліся ў гэты час, вобразна кажучы, можна лічыць перакідным мастом у новую беларускую літаратуру" [Шакун 1984: 174]. Аднак, нягледзячы на такую важную ў гістарычным плане ролю, XVIII ст. з'яўляецца найменш асэнсаваным і даследаваным перыядам у гісторыі беларускай мовы.

Як нам уяўляецца, дыяметральныя азначэнні ў адносінах да беларускай мовы твораў XVIII ст., роўна як і супрацьлеглыя погляды на праблему перарыву пісьмовай традыцыі ў суме з рознымі інтэрпрэтацыямі гэтых поглядаў узніклі з-за розных крытэрыяў, пакладзеных у аснову агульнай перыядызацыі беларускай літаратурнай мовы. На важнасць якасці такіх крытэрыяў указвае ў сваім артыкуле Дыскусійныя праблемы перыядызацыі гісторыі беларускай літаратурнай мовы (2019) прафесар Г. Кулеш: “Уяўленне аб развіцці літаратурнай мовы на працягу ўсёй гісторыі яе функцыянавання будзе дакладным толькі ў тым выпадку, калі яно сфарміруецца на дакладна пабудаванай схеме" [Кулеш 2019: 26]. Сама па сабе думка слушная і даўняя - аўтар названага артыкула згадвае, што "важнасць дастаткова абгрунтаваных прынцыпаў перыядызацыі падкрэсліваў Л. Шакун” [Кулеш 2019: 26].

Такім чынам, канстатуем існаванне тэзіса пра малалікасць помнікаў беларускага пісьменства XVIII ст., а таксама існаванне розных 
інтэрпрэтацый значэння нешматлікіх наяўных ад гэтага часу твораў інтэрпрэтацый, звязаных з рознымі крытэрыямі, пакладзенымі ў аснову перыядызацыі беларускай літаратурнай мовы.

\section{3. Беларускамоўныя лацінаграфічныя тэксты XVIII ст.}

Наступным лагічным ходам з'яўляецца верыфікацыя існуючага стэрэатыпнага меркавання пра малалікасць помнікаў беларускага пісьменства XVIII ст. Разумеючы глабальнасць і працаёмістасць дадзенай задачы, засяродзімся толькі на лацінаграфічных тэкстах, маючы на ўвазе пры гэтым, што акрамя іх існуюць яшчэ кірылічныя і арабаграфічныя. Уяўленне пра арабаграфічныя беларускамоўныя тэксты можна скласці, напрыклад, абапіраючыся на даследаванні М. Тарэлкі, А. Цітавец, а таксама на складзеныя імі каталогі [Рукапісы татараў... 2011; Рукапісы татараў... 2015]. У колькасных адносінах кірылічных тэкстаў XVIII ст., верагодна, менш, чым лацінаграфічных. Абапіраючыся на той факт, што Канкарданс беларускай мовы XIX cm. (2015) фіксуе 309 тэкстаў, напісаных / надрукаваных лацінкай, і 188 - кірыліцай [Канкарданс 2015], можна выказаць меркаванне, што тэндэнцыя да пашырэння лацінскай графічнай сістэмы для пісьмовай перадачы беларускага маўлення была актуальнай і ў папярэднім XVIII ст.

Адзначым, што выкарыстанне лацінаграфічнай сістэмы для перадачы славянскага маўлення на пісьме вядома яшчэ з VIII-IX стст. Так, створаная Кірылам і Мяфодзіем адметная славянская азбука прыйшла на замену чужой (грэчаскай) мове першых пісьмовых тэкстаў славян (надпісы балгарскіх уладароў канца VIII - першай паловы IX ст.) і спробам транслітараваць славянскае маўленне грэчаскім або лацінскім пісьмом (VIII-IX стст.) [Флоря 1997, I: 97-98].

Гаворачы пра беларускае лацінаграфічнае пісьменства старажытнай пары, часцей за ўсё уцзгадваюць творы, якія могуць быць аднесены да мастацкай літаратуры: а) інтэрмедыі і інтэрлюдыі пад умоўнымі назвамі (Селянін у касцёле, Селянін на споведзі, Інтэрмедыя, Мужык і гарбар і інш.) і вядомыя яшчэ з канца XVI ст. [Ціванова 1989: 29-30], росквіт якіх як жанру можна бачыць у п'есах Камедыя (1787) Каятана Марашэўскага і Лекар па прымусу (к. XVIII ст.) Міхала Цяцерскага; б) сатырычныя празаічныя творы Ад Макарыя і Грамата, пісаная да Святога Пятра (п. XVII ст.), Сенька Налівайка... (1642), Прамова Мялешкі (п. п. XVII ст.), Ліст да Абуховіча (1655), Прамова русіна (п. п. XVIII ст.), Другая прамова Русіна аб нараджэнні Хрыста (п. п. XVIII ст.); в) асобныя ананімныя рэлігійныя і свецкія вершы-песні і творы школьнага вершапісання. Другую значную частку старажытных беларускамоўных лацінаграфічных тэкстаў складаюць летапісныя творы: Хроніка Быхаўца (1542-1543 гг.), Альшэўскі летапіс (1550), а таксама Хроніка Панцырнага і Аверкі, Магілёууская хроніка (абедзве датуюцца XVII-XIX стст.). Нельга не ўзгадаць тут і пра знакаміты Моладаўскі звон 1583 г., надпіс 
на якім зроблены лацінскай графікай (в. Моладава знаходзіцца ў Іванаўскім раёне Брэсцкай вобласці).

Заўважым, што ў публікацыях Георгія Галенчанкі, Сяргея Гараніна, Ігара Клімава, Дзяніса Лісейчыкава, Алены Рудэнка, Алены Сурковай, Алеся Сушы і іншых сучасных даследчыкаў можна знайсці звесткі і пра цікавыя ў межах акрэсленай тэмы беларускамоўныя творы.

Лічым, што ў дадзенай публікацыі мэтазгодна не паўтараць агульнавядомую інфармацыю, а засяродзіцца на малавядомых беларускамоўных лацінаграфічных творах і на тых, што няўдаўна ўведзены ў навуковы зварот.

\section{Літаратурныя творы}

У сакавіцкім нумары часопіса "Роднае слова" за гэты год апублікаваны надзвычай важны для нашай тэмы і праблемы артыкул Антона Францішка Брыля Барунскія святочныя маналогі. Беларускія вершы сярэдзіны XVIII cm. у базыльянскім рукапісе [Брыль 2020]. У артыкуле паведамляецца пра тры выяўленыя аўтарам у бібліятэцы Акадэміі навук Літвы імя Урублеўскіх рукапісы Нікадзіма Грыневіча, базыльянскага святара і выкладчыка рыторыкі ў Барунах. У адным томе сярод іншага змешчаны невялікія вершы 1751-1752 гадоў, запісаныя лацінкай, але з кірылічнымі загалоўкамі. Як адзначае аўтар, “мова многіх вершаў - выразна беларуская, хоць і з дамешкам паланізмаў і ўкраінізмаў" [Брыль 2020: 11]. Вершы ўяўляюць сабой камічныя маналогі стральца, селяніна, купца рыбы, кухты - і адначасова гэта - фрагменты, якія "мусілі быць часткаю каляднага прадстаўлення, дзе акцёры чаргавалі жартоўныя промовы-інтэрмедыі з тэматычнымі пабожнымі вершамі, напісанымі да свята" [Брыль 2020: 11].

Цікавыя звесткі трапіліся нам у Описании рукописного отделения Виленской публичной библиотеки (1906), дзе ў раздзеле III Описание рукописных сборников на польском и латинском языках пад № 13 значыцца Сборник гимнов и песней религиозного содержания, так называемых kolęd на день Рождества Христова, на польском, латинском и руском языках. У зборніку № 13 на с. 68 і 74 змешчаны “два (песнопения M. C.) на белорусском наречии, писанные, впрочем, польскими буквами" [Описаніе... 1906: 105], а у самім Описании... прыводзяцца цалкам тэксты гэтых калядак, праўда, ужо ў кірылічным запісе [Описаніе... 1906: 105-106]. На жаль, нічога не паведамляецца пра час стварэння зборніка; невядома нам і пра яго лёс. Атрыбуцыі гэтых твораў можа дапамагчы філалагічнае вывучэнне тэкстаў.

У 1760-х гг., прыкладна на дзесяцігоддзе пазней за Барунскія святочныя маналогі, узніклі сатырычныя творы Ukaz goraczy polkom rossyiskim... i Projekt ... woysku Rossyiskoти..., выяўленыя Адамам Мальдзісам у фондах Цэнтральнай бібліятэкі АН Літоўскай ССР і апісаныя ім яшчэ ў 1970-я гады. Аднак, як заўважае Вячаслаў Мартысюк, яны не былі 
апублікаваны 3-за дзвюх прычын: “Першая: яны ўтрымліваюць абсцэнізмы, а другая - маюць яўна антырасійскі характар" [Мартысюк 2016а: 307]. Зразумела, што з-за гэтых жа прычын творы фактычна так і не сталі аб'ектам навуковага даследавання.

Няпросты лёс напаткаў і верш пад назвай Piesnia biełaruskich źaunierou (1794), пра які ўпершыню загаварылі ў 1935 г. і арыгінал якога быў выяўлены таксама А. Мальдзісам у фондах Цэнтральнай бібліятэкі АН Літоўскай ССР на пачатку 1970-х гадоў. Аднак гэты верш мае ўжо не сатырычны, як папярэдне названыя, а востры палітычны характар і ўяўляе сабой “першы ў беларускай літаратуры непасрэдны заклік да народных мас узяць у рукі зброю, «косы ды янчаркі», каб самім вырашыць лёс Радзімы, «гордыя гнуць каркі» знешніх ворагаў і ўнутраных здраднікаў" [Гісторыя... 2006, II: 19]. Невыпадкова Анатоль Трафімчык, які даследаваў Piesniu... і яе ролю ў літаратурным працэсе, называе гэты верш “індыкатарам беларускай мадэрнасці" [Трафімчык 2016].

Заўважым, што рэлігійнае і свецкае беларускамоўнае вершапісанне XVIII - пачатку XIX ст. наогул рэдка выступае (?) аб'ектам мовазнаўчага даследавання. Не ў апошнюю чаргу гэта звязана з тым, што ў літаратуразнаўчых крыніцах, як правіла, прыводзіцца адаптаваны, малапрыдатны для мовазнаўчага вывучэння тэкст, і нават не паведамляецца пра тое, кірыліцай ці лацінкай ён напісаны ў арыгінале (гл., напр. [Гісторыя... 1967, I: 416-421; Гісторыя... 2006, I] і інш.). Адным 3 нямногіх выключэннем з'яўляецца падрыхтаванае Алесем Бразгуновым выданне Славянамоўная паэзія Вялікага Княства Літоўскага XVIXVIII cmcm. (2011), у якім змешчаны арыгінальныя тэксты старажытных твораў i ix пераклады на сучасную беларускую мову [Славянамоўная паэзія... 2011]. Цяжкадаступнасць арыгіналаў твораў, раскіданасць іх па розных зборніках і крыніцах вядуць да таго, што яны так і застаюцца на перыферы навуковага даследавання. А мовазнаўчае вывучэнне твораў менавіта гэтых літаратурных жанраў магло б многае даць для высвятлення дынамікі працэсаў, што адбываліся ў тагачаснай беларускай літаратурнай мове на шляху яе станаўлення на народнагутарковай аснове і ў сувязі з папярэдняй пісьмовай традыцыяй.

\section{Афіцыйна-справавыя дакументы}

Прафесар Ягелонскага ўніверсітэта ў Кракаве гісторык Юры Гардзееў, пішучы ў адной са сваіх прац пра XVIII ст., паведамляе:

Не з'яўляецца сакрэтам факт, што ў канцылярыях таго часу старабеларускія тэксты XVI-XVIII стст. не перакладаліся на польскую, а перапісваліся на мове арыгіналу лацінкай (вылучана намі - M. С.). Гэта паказвае на тое, што пісары гарадскіх рад і лаў, земскіх і гродскіх судоў нароўні з польскай ведалі беларускую мову - чыталі і перапісвалі старабеларускія дакументы [Гардзееў 2007: 101].

Справядлівасць гэтага выказвання падмацоўвае, напрыклад, змест артыкула Старабеларускія граматы XV cm. з Archiwum Głównego Akt 
Dawnych у Варшаве [Ліцкевіч 2009], аўтар якога, Алег Ліцкевіч, паведамляе пра 23 старабеларускія арыгінальныя дакументы і яшчэ адзін, вядомы ў некалькіх пазнейшых копіях. Якраз два варыянты копій граматы князя Аляксандра Уладзіміравіча касцёлу св. Міхаіла ў Слуцку (01.09.1444-28.02.1445, Кіеў) і захаваліся ў лацінаграфічных запісах 1696 і 1717 гг. [Ліцкевіч 2009: 13-15]. Пра першы варыянт копіі паведамляецца, што ў ім ёсць "шматлікія скажэнні, выкліканыя кепскім разуменнем кірылічнага пратографа" [Ліцкевіч 2009: 13].

Лацінская графіка для запісу старабеларускай мовы была выкарыстана ў выключна арыгінальным дакуменце, пра які паведаміў Д. Лісейчыкаў у артыкуле, змешчаным у зборніку “Архіварыус" (2016). Гаворка пра сфальсіфікаваную візітацыю ўніяцкай царквы ў в. Дзмітравічы Аршанскага павета. Візітацыя датавана 1621 г., але на самай справе, як лічыць і абгрунтавана даказвае Д. Лісейчыкаў, "найбольш верагодны час стварэння падробкі - другая палова 1760-х гадоў" [Лісейчыкаў 2016: 165 і інш.], яна была зроблена адміністратарам царквы Іосіфам Карніловічам [Лісейчыкаў 2016: 167 і інш.]. Візіта ўяўляе сабой транслітарацыю лацінкай з нібыта арыгінальнага кірылічнага дакумента [Лісейчыкаў 2016: 167]. Вельмі каштоўная для нашага даследавання наступная інфармацыя, змешчаная ў артыкуле Д. Лісейчыкава:

Увагу таксама не мог не прыцягнуць той факт, што “візіту 1621 года" Іосіф Карніловіч ствараў на "рускай" (старабеларускай) мове. Гэта пры тым, што да нашага часу не дайшло ніводнай візіты, складзенай “паруску” (вылучана намі - M. C.). Пачынаючы ад самага ранняга вядомага пісьмовага пратакола генеральнай візітацыі 1676 г. да канца XVIII ст., усе яны складаліся па-польску, і толькі ў часы Расійскай імперыі асобныя пратаколы генеральных візітацый на беларуска-літоўскіх землях складаліся на рускай (тут узначэнні “расійскай”) мове [Лісейчыкаў 2016: 170].

Такім чынам, гэты фальсіфікат - адзіны ў сваім родзе - сведчыць, што 1) па ўяўленнях фальсіфікатара візітацыі ў канцы XVI - на пачатку XVII ст. складаліся на старабеларускай мове; 2) у другой палове 1760-х гадоў пісаць лацінкай для фальсіфікатара было больш натуральна, чым кірыліцай; трэба мець на ўвазе і тое, што сфальсіфікаваная візітацыя падчас легалізацыі ў XVIII ст. выступала разам з іншымі датычнымі яе дакументамі, напісанымі па-польску.

Хочацца спадзявацца, што пералік гістарычных дакументаў ад канца XVII - XVIII і да пачатку XIX стст., напісаных па-беларуску лацінкай, якія трапілі ў поле ўвагі навукоўцаў нядаўна, у хуткім часе можна будзе працягнуць.

Да ліку дакументальных неабходна далучыць і літаратурныя адкрыцці, якія адносяцца, што праўда, да пачатку - першай паловы XIX ст. Так, вельмі цікавую і важную знаходку зрабіў у 2014 г. у аддзеле рукапісаў бібліятэкі князёў Чартарыйскіх у Кракаве Лявон Баршчэўскі. У архіўных матэрыялах князёў Друцкіх-Любецкіх са Шчучына яму пашчасціла знайсці запісаныя лацінкай па-беларуску самастойны твор 
Wiersz Ruski o Religii i Obyczajności і верш Jasno czerwony raczek po obłoku skacze..., якія могуць быць датаваны другой паловай 1810 - 1824 гг., пра што аўтар знаходкі і Язэп Янушкевіч паведамілі ў сумеснай публікацыі 2016 г., змешчанай у 16-м томе "Acta Albaruthenica" [Баршчэўскі 2016: 316]. Усё гэта сведчыць пра тое, што ў шляхецкіх архівах могуць знаходзіцца і іншыя пакуль не адшуканыя беларускамоўныя сведчанні з папярэдняга XVIII ст.

У гэтым жа томе В. Мартысюк паведаміў і ўпершыню апублікаваў лацінаграфічны прывітальны верш пад назвай Barys, які датуецца першай паловай XIX ст. і знаходзіцца ў рукапісных зборах Яна Чачота ў Вільні [Мартысюк 2016b], а Мікола Хаўстовіч прааналізаваў і апублікаваў верш Fantazya biało-ruska, упершыню апублікаваны ў 1859 г. (а значыць, створаны раней) і шырока вядомы амаль дэтэктыўнай гісторыяй свайго ўваходжання ў навуковы і літаратурны дыскурс [Хаўстовіч 2016].

\section{Канфесійнае пісьменства}

Ёсць падставы меркаваць, што раней невядомыя беларускамоўныя (найперш лацінаграфічныя) тэксты XVIII ст. будуць выяўленыя сярод пісьмовай спадчыны ўніяцкай царквы. I гэта могуць быць як дакументы, так і розныя зборнікі рэлігійнага зместу - разнародныя ў жанравых адносінах творы. Так, напрыклад, як асобны і абсалютна недаследаваны літаратурны жанр разглядаюцца апавяданні пра цудоўныя здарэнні (што адбываліся пры цудадзейных іконах) у выступленні Сяргея Гараніна на XVI Міжнародных кнігазнаўчых чытаннях, прымеркаваных да 500-годдзя Жыровіцкага манастыра і бібліятэкі [Гаранін 2020]. Цікавыя звесткі на гэты конт знаходзяцца таксама ў артыкуле Алеся Сушы, які выявіў у фондах Львоўскай нацыянальнай навуковай бібліятэкі Украіны імя В. Стэфаніка вялікі фрагмент трэцяй часткі гэтак званага Жыровіцкага рукапісу з такімі запісамі аб цудоўным ацаленні [Суша 2009].

\section{Высновы}

Разважанні над характарам вядомых у сучаснасці беларускамоўных лацінаграфічных тэкстаў XVIII ст., акрамя спадзяванняў на новыя знаходкі, дазваляе выказаць абагульненні адносна наступных крытэрыяў:

1. Прычыны стварэння. Аўтары, якія валодалі польскай і беларускай мовамі, звярталіся да лацінаграфічнай сістэмы пісьма галоўным чынам з-за яе натуральнасці для ix, зручнасці выкарыстання для адукаванага чалавека, які засвоіў лацінаграфічнае і не засвоіў кірылічнае пісьмо. Уласная маўленчая практыка і арыентацыя на рэцыпіента вымагала ўжывання беларускай мовы, а існаваўшая на той час пісьмовая традыцыя спрыяла выкарыстанню агульнапашыранай і агульнавядомай лацінскай графікі. 
2. Мэты выкарыстання. Тут неабходна гаварыць не столькі пра мэты выкарыстання лацінскай графікі для запісу беларускага маўлення (зразумела, што асноўная мэта - перадача беларускага маўлення), колькі пра сам факт звароту да яго запісу. Як нам бачыцца, асноўныя мэты такога звароту - парадыйна-стылістычная ў шэрагу вершаў, інтэрмедыях і інтэрлюдыях, а таксама - і гэта намнога больш важна! уласна камунікатыўная і інспіратыўная ў асобных нешматлікіх творах, колькасць якіх будзе паступова ўзрастаць у XIX ст., што ў сваю чаргу забяспечыць пераход да якасна новага стану беларускай літаратуры і беларускай літаратурнай мовы.

3. Пошукі новых крыніц. Далейшае плённае даследаванне беларускай мовы XVIII ст. цяжка ўявіць без увядзення ў навуковы зварот раней невядомых або малавядомых тэкстаў. Іх пошукі не павінны абмяжоўвацца сферай мастацкай літаратуры і публіцыстыкі; да гэтага павінна быць прыцягнутая афіцыйна-справавое пісьменства, прадстаўленае - ці не найперш - дакументамі, якія адносяцца да дзейнасці ўніяцкай царквы: візітацыі, інвентары, кнігі запісаў, спісы прыхаджан і пад. Тое ж самае можна сказаць пра мемуарыстыку - асабістыя і сямейныя запісы, мемуары, дзённікі-дыярыушы, зборнікі "silva rerum", салонныя альбомы і пад. могуць аказацца адной з тых крыніц, што дапамогуць узнавіць больш поўную карціну функцыянавання беларускай мовы ў XVIII ст. У працэсе напаўнення факталагічнай базы варта зыходзіць 3 таго, што самастойны закончаны твор або дакумент на беларускай мове можна выявіць у складзе больш аб'ёмнага твора або дакумента на польскай мове.

У заключэнне можна зрабіць выснову аб тым, што ў сучасным навуковым дыскурсе праблемы, звязаныя з функцыянаваннем беларускай мовы на працягу XVIII ст., наяўнасцю перарыву ў яе літаратурна-пісьмовай традыцыі і пераемнасцю паміж старабеларускім перыядам і перыядам новай беларускай літаратурнай мовы павінны падвяргацца крытычнаму пераасэнсаванню, а таксама верыфікавацца з улікам раней невядомых або малавывучаных фактаў - беларускамоўных лацінаграфічных твораў XVIII ст., якія часткова запаўняюць “беспісьмовую" лакуну ў яе гісторыі.

\section{Бібліяграфія}

Aničenko Vladimir. 1978. Razvitie belorusskogo literaturnogo âzyka v XVIII v. "Voprosy âzykoznaniâ" № 4: 47-57. [Аниченко Владимир. 1978. Развитие белорусского литературного языка в XVIII в. “Вопросы языкознания” № 4: 47-57].

Barščèǔskì Lâvon, Ânuškevič Âzèp. 2016. Dva novyâ tèksty belaruskaj litaratury XIX st.: Žanravâ̂ prynaležnasc', moǔnyâ asablìvascì, prablemy atrybucyì. "Acta Albaruthenica” 16: 311-322. [Баршчэўскі Лявон, Янушкевіч Язэп. 2016. Два новыя тэксты беларускай літаратуры ХІХ ст.: Жанравая прыналежнасць, моўныя асаблівасці, праблемы атрыбуцыі. "Acta Albaruthenica" 16: 311-322].

Bryl' Anton Francì̌ak. 2020. Barunskiâ svâtočnyâ manalogì. Belaruskiâ veršy sârèdzìny XVIII st. u bazyl'ânskìm rukapìse. “Rodnae slova” № 3: 11-13. [Брыль Антон 
Францішак. 2020. Барунскія святочныя маналогі. Беларускія вершы сярэдзіны XVIII ст. у базыльянскім рукапісе. “Роднае слова” № 3: 11-13].

Cìvanova Galìna. 2007. Prablema peraemnascì pamiž starym ì novym belaruskìm pìs'menstvam. U: Mova - Litaratura - Kul'tura: Matèr. V mižnar. navuk kanf. (da 80-goddzâ praf. L.M.Šakuna) (16-17.11.2006). Mìnsk: Prava ì èkanomìka [Ціванова Галіна. 2007. Праблема пераемнасці паміж старым і новым беларускім пісьменствам. У: Мова - Літаратура - Культура: Матэр. V міжнар. навук канф. (да 80-годдзя праф. Л.М. Шакуна) (16-17.11.2006). Мінск: Права і эканоміка].

Cìvanova Galìna. 2010. Vyrašènne A.İ.Žuraǔskìm prablemy peraemnascì pamiž staroj ì novaj belaruskaj litaraturnaj movaj. U: Belaruskae slova: gìstoryâ ì sučasnasc': zb. artyk. pa matèr. navuk. čytannâŭ, prysv. pamâcì praf. A.İ. Žuraǔskaga (Mìnsk, 27.10.2009). Mìnsk: Prava ì èkanomìka [Ціванова Галіна. 2010. Вырашэнне А.І. Жураўскім праблемы пераемнасці паміж старой і новай беларускай літаратурнай мовай. У: Беларускае слова: гісторыя і сучаснасць: зб. артык. па матэр. навук. чытанняў, прысв. памяці праф. А.І.Жураўскага (Мінск, 27.10.2009). Мінск: Права і эканоміка].

Florâ Boris. 1997. Vozniknovenie slavânskoj pis'mennosti. V: Istoriâ literatur zapadnyh i ûžnyh slavân v treh tomah. Moskva: Indrik [Флоря Борис. 1997. Возникновение славянской письменности. В: История литератур западных и южных славян в трех томах. Москва: Индрик].

Gaponenka Ìryna. 2010. Pytannì moǔnaj peraemnascì ǔ pracah belaruskìh iǔkraìnskìh lìngvistaǔ. U: Belaruskae slova: gìstoryâ ì sučasnasc': zb. artyk. pa matèr. navuk. čytannâǔ, prysveč. pamâcì praf. A.İ. Žuraǔskaga (Mìnsk, 27.10.2009). Mìnsk: Prava ì èkanomìka [Гапоненка Ірына. 2010. Пытанні моўнай пераемнасці ў працах беларускіх і ўкраінскіх лінгвістаў. У: Беларускае слова: гісторыя і сучаснасць: зб. артык. па матэр. навук. чытанняў, прысвеч. памяці праф. А.І. Жураўскага (Мінск, 27.10.2009). Мінск: Права і эканоміка].

Garanìn Sârgej. 2020. Žyrovickiâ kazannì ǔ kantèksce rèligìjnaj kul'tury staražytnaj Belarusì [Гаранін Сяргей. 2020. Жыровіцкія казанні ў кантэксие рэлігійнай культуры старажытнай Беларусі [online] https://www.youtube.com/watch ?v=bg4WrekmWOg\&list=PL57KirTlkkGUVSrOrsvxdm60EgCLnAApv\&index=6\&t $=316 \mathrm{~s}$ [доступ: 19.05.2020]].

Gardzeeǔ Ûry. 2003. Da moǔnaj prablematykì garadskìh knìg navačasnaj Goradnì. "Belaruskì gìstaryčny aglâd" t. 10, sš. 1-2: 121-142 [Гардзееў Юры. 2003. Да моўнай праблематыкі гарадскіх кніг навачаснай Горадні. “Беларускі гістарычны агляд" т. 10, сш. 1-2: 121-142].

Gardzeeǔ Ûry. 2007. Gìstoryâ belaruskaj movy ǔ 18 st. (krynìcaznaǔčy aspekt). U: Mova Litaratura - Kul'tura: Matèr. V mižnar. navuk. kanf. (da 80-goddzâ praf. L.M. Šakuna) (Mìnsk, 16-17.11.2006). Mìnsk: Prava ì èkanomìka [Гардзееў Юры. 2007. Гісторыя беларускай мовы ў $18 \mathrm{~cm}$. (крыніцазнаўчы аспект). У: Мова - Літаратура - Культура: Матэр. V міжнар. навук. канф. (да 80-годдзя праф. Л.М. Шакуна) (Мінск, 16-17.11.2006). Мінск: Права і эканоміка].

Getka Ioanna. 2018. Belorusskij âzyk XVIII v. - issledovatel'skie postulaty. "Studia исследовательские постулаты Białorutenistyczne" 12: 177-190 [Гетка Иоанна. 2018. Белорусский язык XVIII в. -. "Studia Białorutenistyczne” 12: 177-190].

Getka Joanna. 2017. U progu modernizacji. Ruskojęzyczne drukarstwo bazyliańskie XVIII wieku. Warszawa: Katedra Studiów Interkulturowych Europy ŚrodkowoWschodniej.

Getka Joanna. 2018. Ruskojęzyczne wydania drukarni supraskiej o charakterze religijnym (XVIII wiek) - pominięty element $w$ badaniach nad historiq kultury białoruskiej. W: „Z Polskich Studiów Slawistycznych”, seria 13, t. 1: 45-54. 
Gìstoryâ belaruskaj litaraturnaj movy u dvuh tamah. 1967. Sklad. A.Ì. Žuraǔskì, İ.Ì. Kramko, A.K. Ûrèvìc, A.İ. Ânovič. Mìnsk: Navuka ì tèhnìka. [Гісторыя беларускай літаратурнай мовы ў двух тамах. 1967. Склад. А.І. Жураўскі, I.I. Крамко, А.К. Юрэвіч, А.І. Яновіч. Мінск: Навука і тэхніка].

Gìstoryâ belaruskaj litaratury XI-XIX stagoddzâǔ u dvuh tamah. 2006. Red. U. Marhel', V. Čamârckì. Mìnsk: Belaruskaâ navuka [Гісторыя беларускай літаратуры XIХІХ стагоддзяў у двух тамах. 2007. Рэд. У. Мархель, В. Чамярцкі. Мінск: Беларуская навука].

Gordziejew Jerzy. 2004a. Materiały źródłowe do dziejów Wielkiego Księstwa Litewskiego. Cz. 2. Z zagadnień skarbowości w dobie Stanisławowskiej. "Rocznik Biblioteki Naukowej PAU i PAN w Krakowie", rok XLIX: 127-166.

Gordziejew Jerzy. 2004b. Uwagi o białorusko-polskich kontaktach językowych w miastach Wielkiego Księstwa Litewskiego. "Studia Slavica Hung." t. 49, nr. 3-4: 281-294.

Haǔstovič Marylâ. 2018. Seńko Nálewáyko pouczyćiełowi sáskiemu pouczenie o hreczyśie...: Starabelaruskaâ mova ǔ ezuickaj satyry XVII st. "Acta Albaruthenica" 18: 271-279 [Хаўстовіч Марыля. 2018. Seńko Nálewáyko pouczyćiełowi sáskiemu pouczenie o hreсzуśie...: Старабеларуская мова ў езуіцкай сатыры XVII cm. "Acta Albaruthenica" 18: 271-279].

Haǔstovič Mìkola. 2016. Nevâdomy verš Âna Čačota? "Acta Albaruthenica” 16: 335-338 [Хаўстовіч Мікола. 2016. Невядомы верш Яна Чачота? “Acta Albaruthenica” 16: 335-338].

Kankardans belaruskaj movy XIX stagoddzâ. 2015. Aǔtar-sklad. N.M. Sânkevìč [Èlektronny rèsurs]. Mìnsk: Belaruskaâ navuka [Канкарданс беларускай мовы ХIX стагоддзя. 2015. Аўтар-склад. Н.М. Сянкевіч [Электронны рэсурс]. Мінск: Беларуская навука].

Kuleš Ganna. 2019. Dyskusìnyâ prablemy peryâdyzacyì gìstoryì belaruskaj lìtaraturnaj movy. "Rodnae slova" № 8: 26-29 [Кулеш Ганна. 2019. Дыскусійныя праблемы перыядызацыі гісторыі беларускай літаратурнай мовы. “Роднае слова” № 8: 26-29].

Lìckevìc Aleg. 2009. Starabelaruskîa gramaty XV st. z Archiwum Głównego Akt Dawnych u Varšave. U: "Zdabytkì: dakumental'nyâ pomnìkì na Belarusì” vyp. 11: 6-41 [Ліцкевіч Алег. 2009. Старабеларускія граматы XV cm. з Archiwum Głównego Akt Dawnych у Варшаве. У: “Здабыткі: дакументальныя помнікі на Беларусі" вып. 11: 6-41].

Lìsejčykaǔ Dzânìs. 2016. “Poneże Swiaty Sobor Zamoyski krypko poweliwait...”: sfal'sìilkavanâ̂ vìita carkvy ǔ v. Dzmitravičy Aršanskaga paveta Vâlikaga Knâstva Litoǔskaga 1621 g. "Arhìvaryus" vyp. 14: 158-174 [Лісейчыкаў Дзяніс. 2016. “Poneże Swiaty Sobor Zamoyski krypko poweliwait...": сфальсіфікаваная візіта царквы ў в. Дзмітравічы Аршанскага павета Вялікага Княства Літоўскага 1621 г. “Архіварыус" вып. 14: 158-174].

Martysûk Vâčaslaǔ. 2016a. Dzve veršavanyâ satyry z XIII st. "Acta Albaruthenica” 16: 307309 [Мартысюк Вячаслаў. 2016а. Дзве вершаваныя сатыры з XIII cm. "Acta Albaruthenica" 16: 307-309].

Martysûk Vâčaslaǔ. 2016b. Nedrukavany belaruskì vìnšaval'ny verš z peršaj palovy XIX stagoddzâ ǔ zborah Âna Čačota. "Acta Albaruthenica” 16: 331-334 [Мартысюк Вячаслаў. 2016b. Недрукаваны беларускі віншавальны верш з першай паловы ХІХ стагоддзя ў зборах Яна Чачота. "Acta Albaruthenica" 16: 331-334].

Opisanie rukopisnogo otdeleniâ Vilenskoj publičnoj biblioteki. 1906. Vyp. 5, č. 2: 105-106 [Описание рукописного отделения Виленской публичной библиотеки. 1906. Вып. 5, ч. 2: 105-106].

Rukapisy tataraǔ Belarusì kanca XVII - pačatku XX st. z dzâržaǔnyh knìgazboraǔ kraìny: katalog. 2011. Sklad. M. U. Tarèlka, A. İ. Cìtavec. Mìnsk: Belaruskaâ navuka 
[Рукапісы татараў Беларусі канца XVII - пачатку XX ст. з дзяржаўных кнігазбораў краіны: каталог. 2011. Склад. М. У. Тарэлка, А. І. Цітавец. Мінск: Беларуская навука].

Rukapisy tataraǔ Belarusì XVIII - pačatku XXI stagoddzâ z dzâržaǔnyh ì gramadskìh knìgazboraǔ kraìny: katalog. 2015. Sklad. M.U.Tarèlka. Mìnsk: Belaruskaâ navuka [Рукапісы татараў Беларусі XVIII - пачатку XXI стагоддзя з дзяржаўных і грамадскіх кнігазбораў краіны: каталог. 2015. Склад. М.У.Тарэлка. Мінск: Беларуская навука].

Šakun Leǔ. 1984. Gìstoryâ belaruskaj litaraturnaj movy. Vyd-ne 2-e, peraprac. Mìnsk: Unìversìtèckae [Шакун Леў. 1984. Гісторыя беларускай літаратурнай мовы. Выд-не 2-е, перапрац. Мінск: Універсітэцкае].

Slavânamoǔnaâ paèzîâ Vâlìkaga Knâstva Litoǔskaga XVI-XVIII stst. 2011. Uklad. pradm. ì kament. A.U. Brazgunova. Mìnsk: Belaruskaâ navuka [Славянамоўная паэзія Вялікага Княства Літоўскага XVI-XVIII cmcm. 2011. Уклад. прадм. і камент. А.У. Бразгунова. Мінск: Беларуская навука].

Suša Ales'. 2009. Lës kul'turnaj spadčyny grèka-katalìckaj carkvy ǔ Belarusì: novyâ znahodkì ǔ l'voǔskìh zborah. U: "Zdabytkì: dakumental'nyâ pomnìkì na Belarusì" vyp. 11: 88-130 [Суша Алесь. 2009. Лёс культурнай спадчыны грэка-каталіцкай царквы ў Беларусі: новыя знаходкі у львоўскіх зборах. У: “Здабыткі: дакументальныя помнікі на Беларусі" вып. 11: 88-130].

Tivanova Galina. 1989. Osobennosti âzyka belorusskoj pis'mennosti XVIII veka: avtoref. dis. kand. filol. nauk. Minsk [Тиванова Галина. 1989. Особенности языка белорусской письменности XVIII века: автореф. дис. канд. филол. наук. Минск].

Trafimčyk Anatol'. 2016. "Pesnâ belaruskìh žaǔneraǔ 1794 goda" âk ìndykatar zaradžènnâ madèrnaj belaruskascì: да 270-годдзя Тадэвуша Касцюшкі. “Роднае слова” № 2: 73-77 [Трафімчык Анатоль. 2016. “Песня беларускіх жаўнераў 1794 года” як індыкатар зараджэння мадэрнай беларускасці: да 270-годдзя Тадэвуша Касцюшкі. “Роднае слова” № 2: 73-77].

Žuraǔlëva Ganna. 2018. Užyvanne lacinskaga alfavitu ǔ sučasnaj belaruskaj move. "Acta Albaruthenica” 18: 254-259 [Жураўлёва Ганна. 2018. Ужыванне лацінскага алфавіту у сучаснай беларускай мове. "Acta Albaruthenica" 18: 254-259].

Žuraǔskì Arkadz', Kramko Ìvan. 1973. Haraktar znešnìh uzaemaadnosìn belaruskaj litaraturnaj movy z ìnšymì slavânskìmì movamì ǔ pačatkovy peryâd âe farmìravannâ. Mìnsk: Navuka ì tèhnìka [Жураўскі Аркадзь, Крамко Іван. 1973. Характар знешніх узаемаадносін беларускай літаратурнай мовы з іншымі славянскімі мовамі ў пачатковы перыяд яе фарміравання. Мінск: Навука і тэхніка].

ABSTRACT: The article is devoted to the problem of continuity between the old Belarusian period and the period of the new Belarusian literary language, as well as to Latin graphic texts of the $18^{\text {th }}$ century. The most widespread opinion about the existence of a break in the written tradition of the Belarusian literary language was not the only one before, but now it is being critically analyzed. The article considers the linkages between the continuity of the Belarusian literary language and the problem of its periodization, the concept of Belarusian language history and the history of Belarusian literature. An attempt has been made to refute the stereotypical opinion about the small number of texts of the $18^{\text {th }}$ century Belarusian literature by addressing the little known and recently discovered Latin graphic texts. Conclusions have been made concerning the reasons and aims of using the Latin graphic system for writing in the Belarusian language in the $18^{\text {th }}$ century. An opinion concerning such research directions of the Belarusian texts of that time as memoirs, confessional and official writings has been given as well.

KEYWORDS: Belarusian language, periodization, continuity, Latin alphabet, $18^{\text {th }}$ century. 
STRESZCZENIE: Artykuł jest poświęcony problemowi ciągłości między okresem starobiałoruskim a okresem nowego białoruskiego języka literackiego. Szeroko rozpowszechniony pogląd o istnieniu przerwy w tradycji pisemnej w rozwoju białoruskiego języka literackiego nie był jedyny wcześniej, a teraź jest poddawany analizie krytycznej. Artykuł omawia związek między ciągłością białoruskiego języka literackiego a problemem jego periodyzacji, koncepcją historii języka białoruskiego i historii literatury białoruskiej. Podjęto próbę obalenia stereotypowej opinii o niewielkiej liczbie zabytków literatury białoruskiej XVIII wieku przez odwołanie do mało znanych i niedawno odnalezionych tekstów napisanych alfabetem łacińskim. Sformułowano wnioski na temat przyczyn i celów stosowania w języku białoruskim w XVIII wieku łacińskiego systemu graficznego, zwrócono również uwagę na potrzeby eksploracji ówczesnych tekstów białoruskich w takich obszarach, jak pamiętnikarstwo, piśmiennictwo religijne i urzędowe.

SŁOWA KLUCZOWE: język białoruski, periodyzacja, ciągłość, alfabet łaciński, XVIII wiek.

РЭЗюмЭ: Артыкул прысвечаны праблеме пераемнасці паміж старабеларускай і новай беларускай літаратурнай мовай, а таксама лацінаграфічным тэкстам XVIII ст. Пашыранае меркаванне аб існаванні перарыву пісьмовай традыцыі ў развіцці беларускай літаратурнай мовы не было адзіным і раней, а ў сучаснасці падлягае крытычнаму аналізу. У артыкуле разглядаецца сувязь праблемы пераемнасці беларускай літаратурнай мовы з праблемай яе перыядызацыі, канцэпцыі гісторыі беларускай мовы і гісторыі беларускай літаратуры. Робіцца спроба абвергнуць стэрэатыпнае меркаванне пра малалікасць помнікаў беларускага пісьменства XVIII ст. праз апеляцыю да малавядомых і нядаўна адшуканых лацінаграфічных тэкстаў. Прыводзяцца высновы аб прычынах і мэтах выкарыстання ў XVIII ст. лацінскай графічнай сістэмы для пісьма па-беларуску, а таксама выказваюцца меркаванні адносна такіх напрамкаў для пошуку тагачасных беларускамоўных тэкстаў, як мемуарыстыка, канфесійнае і афіцыйна-справавое пісьменства.

ключАвыя словы: беларуская мова, перыядызацыя, пераемнасць, лацінская графіка, XVIII стагоддзе. 